\title{
Avaliação da função auditiva receptiva, expressiva e visual em crianças prematuras $* * *$
}

\author{
Assessment of receptive and expressive auditory and visual functions \\ in pre-term children
}

\author{
Dionísia Aparecida Cusin Lamônica* \\ Fabiana Cristina Carlino** \\ Kátia de Freitas Alvarenga*
}

*Fonoaudióloga. Livre Docente. Professora Associada do Departamento de Fonoaudiologia da Faculdade de Odontologia de Bauru da Universidade de São Paulo (FOB - USP). Endereço para correspondência: Rua Al. Dr. Octávio Pinheiro Brisolla, 9-75 Bauru - SP - CEP 17012-901

(dionelam@uol.com.br).

**Fonoaudióloga. Mestranda em Educação Especial pela Universidade Federal de São Carlos (SP).

***Trabalho Realizado no Departamento de Fonoaudiologia da FOB - USP.

Artigo Original de Pesquisa

Artigo Submetido a Avaliação por Pares

Conflito de Interesse: não

Recebido em 15.05.2009. Revisado em 11.01.2010. Aceito para Publicação em 01.02.2010.

\begin{abstract}
Background: prematurity as a risk factor for delay in language development. Aim: to verify the performance of premature children regarding their receptive and expressive auditory and visual abilities. Method: participants were 40 children with chronological ages between 12 and 24 months. The experimental group (G1) was composed by 20 children who presented report of prematurity and low or very low weight. The birth age varied from 22 to 34 weeks and weight was below 2500gr. This group was divided according to weight, i.e. children with low and very low weight. The control group (G2) was composed by 20 children born at term, with weight above 2500gr and with no report of development delay. The procedures consisted of an interview with the parents and the application of the Early Language Milestone Scale ELM. Results: when comparing the groups, the results indicate statistically significant differences. Children of G1 presented a poorer performance in the Expressive Hearing (EH), Receptive Hearing (RH) and Visual (V) areas, although a few children of this group presented the expected results for their age group in some of the tested abilities. The expressive auditory ability was the most affected. Conclusion: children of G1 presented deficits in the expressive and receptive auditory and visual functions. Premature children with very low weight presented higher deficits in the tested abilities.
\end{abstract}

Key Words: Premature; Child Development; Child Language; Language Disorders.

\section{Resumo}

Tema: prematuridade como fator de risco para atraso no desenvolvimento da linguagem. Objetivo: verificar o desempenho de crianças prematuras quanto às áreas auditiva receptiva, expressiva e visual. Método: participaram da amostra 40 crianças de idade cronológica entre 12 e 24 meses. O grupo experimental (G1) foi composto por 20 crianças que apresentaram em seu histórico de vida os fatores de risco prematuridade e baixo peso ou muito baixo peso. A idade gestacional das crianças variou de 22 a 34 , semanas todas com peso abaixo de 2500g; este grupo foi dividido em função do peso, ou seja, crianças de baixo peso e de muito baixo peso. O grupo controle (G2) foi composto por 20 crianças nascidas a termo com peso superior a $2500 \mathrm{~g}$, sem histórico para atraso do desenvolvimento. Os procedimentos constaram de entrevista com os pais e aplicação da Escala Early Language Milestone Scale (ELM). Resultados: na comparação entre grupos, os resultados mostraram ser estatisticamente significativos. As crianças do G1 apresentaram prejuízo na área auditiva expressiva, auditiva receptiva e visual, embora algumas crianças tivessem apresentado resultados esperados para sua faixa etária, em alguma das funções avaliadas. A área mais prejudicada foi a área expressiva. Conclusão: as crianças do G1 apresentaram alteração nas áreas auditiva receptiva, auditiva expressiva e visual. As crianças prematuras com muito baixo peso apresentaram maiores prejuízos nas áreas avaliadas.

Palavras-Chave: Prematuro; Desenvolvimento Infantil; Linguagem Infantil; Transtornos de Linguagem.

Referenciar este material como: 


\section{Introduction}

Prematurity is considered a biological risk factor to the typical development of children1-3. Preterm or premature newborn is defined as those born with gestational age below 37 weeks, and as underweight all that are born alive weighing less than $2500 \mathrm{~g}$ at birth4.

Underweight premature newborns are considered at risk for delays in motor, cognitive and language development as per extensive literature5-13. However, the nature of such deficits is not clear6.

The preterm newborn, depending on his degree of immaturity at birth, should continue the development and maturation of various organs and systems during his post-natal period, aiming to reach his full capacity in order to be part of the environment in a dynamic process which can be even one of defense in relation to it14. Authors have presented that the association between prematurity and brain damage is adjacent to the acting region of the periventricular leukomalacia and the periventricular white matter, with or without evolution to the increase of the lateral ventricles that they may affect descending motor fibers of the association cortex and association fibers of the visual, auditory and somesthetic functions15-17. There is also a crucial relationship between language problems and of information processing deficit, especially in the influence of the reception of stimuli that will be integrated and stored and that will establish the understanding of oral language affected by the environment, causing behavioral changes5,6. The information processing disorders are considered multidimensional entities with characteristic qualities and implications for the educational and psychosocial areas, impacting the development of these children8.

In this light, the aim of this study was to verify the performance of premature infants concerning receptive auditory, expressive and visual areas.

\section{Method}

This project was approved by the Ethics Research Committee (protocol number 15/2005) prior to the execution of this study. It is important to emphasize that all ethical principles have been complied with according to Resolution 196/96 of CONEP (Comissão Nacional de Ética em Pesquisa) and that the legal guardians of the participants signed the consent, agreeing with their participation in this study and publication of results.
Participants in this study were divided into two groups. The Experimental Group (G1) was composed of 20 children, born prematurely and of low weight. The Control Group (G2) was composed of 20 children, born at term and weighing more than $2500 \mathrm{~g}$. All children who were part of this study were born in a hospital connected to the National Health System and previously screened at birth with normal results.

The criteria for eligibility of participants in the G1 group were:

. be at least 12 months old but not 24 months old; . be born before 37 weeks and weighing less than 2500g;

. absence of identified neurological syndromes, cerebral palsy or neurological complications, and multiple pregnancies.

The criteria for eligibility of participants in the G2 group were:

. be at least 12 months old but not 24 months old; . be born after 37 weeks, and weighing more than $2500 \mathrm{~g}$, and not be a twin evaluated.

- absence of delay in neuropsychomotor developmental, ensure during the interview with parents, considering the following milestones: cervical balance, ability to sit without support and walk.

Assessment procedures consisted of:

1. An anamnesis answered by one of the parents (legal representatives).The anamnesis used was composed of the following: personal data, information about the pregnancy and birth, information about the first infancy, developmental stages and medical information. Records from the maternity ward with information about the newborns were used.

2. Utilization of the Early Language Milestone Scale (ELM)19. This is considered an abbreviated language evaluation tool. Language milestones were grouped into three areas: receptive auditory (RA) function, expressive auditory (EA) function and visual (V) function. According to this tool19, behaviors are presented in chart form, single-sheet, divided into 36 months, so that each item and the month in which a particular skill started can be located. The graph shows the values of $25 \%, 50 \%$, $75 \%$ and $90 \%$ as representation of the percentage of children of a certain age group that achieved the skill tested during the validation process of the 
scale. Application time depends on the age and skill level of the evaluated individual. Initially we draw a vertical line on the entire scale, exactly on the chronological age of the child to be tested. After that, all items that cross this vertical line in each of the three areas RA, EA, V are evaluated to determine the ceiling and basal levels. The three items of success or failure must be identified in each function. We take into consideration direct testing $(\mathrm{T})$, the parents' feedback $(\mathrm{H})$ or the incidental observation of behavior in question $(\mathrm{O})$. If the child's basal level is in the $90 \%$ percentile on all items and without failure, the child has adequate performance. Failure in one or more items in the $90 \%$ percentile in an attempt to find the basal level requires the determination of the ceiling level for that function. If the value of $75 \%$ in the ceiling item exceeds the child's chronological age, the child has passed the ELM scale.

In regards to the functions assessed, proposed by the ELM scale for the age in question, for example, in the RA, the following items are observed: lateral orientation (bell), vertical orientation (bell) and diagonal orientation (bell), inhibition to no, order a command without gesture, pointing to body parts and pointing to named objects. In the EA area says mamma / dada any; mom / dad first word correctly; knows 4 to 6 words; makes requests: more than 50 single words; 2-word sentence. In the $\mathrm{V}$ area, recognizes parents, recognizes objects, responds to facial expressions, blinks for threatening danger, mimics gesture games, order of a command with gestures, initiates gesture games, point out to desired objects.

We decided to perform the statistical analysis considering the chronological age as opposed to the adjusted age, considering that these children will have their performance evaluated, in social activities and at school, for their chronological age.
The statistical analysis followed the criteria of testing procedures proposed by the ELM scale and nonparametric statistical t-test for dependent samples to compare the scores obtained with the values adopted as reference for the three areas of dominance. Significance level p ?0.05 was adopted.

Characterization of the population: the $\mathrm{G} 1$ group was formed by 10 girls and 10 boys of gestational age ranging from 22 to 34 weeks, with an average of 29.4 weeks of gestation. Birth weight ranged from $820 \mathrm{~g}$ to $2450 \mathrm{~g}$, average of $2030 \mathrm{~g}$. The Apgar score was reported as being altered in $35 \%$ of the children. No child had significant delay in motor development, as determined by criteria for inclusion. From these, 35\% were considered to have very low birth weight, i.e. weighing less than $1500 \mathrm{gr}$ (VLW). G2 was formed by 10 girls and 10 boys ofgestational age ranging from 38 to 41 weeks, paired to G1 by gender and chronological age, with an average of 38.9 gestational weeks. Birth weight ranged from $2830 \mathrm{~g}$ to $3940 \mathrm{~g}$, with an average of 3350g. The average age of G1 and G2 was 16.7 months at the time of evaluation. All children have pediatric follow up in public clinics of their town.

\section{Results}

Table 1 shows, respectively for the RA, EA, and $\mathrm{V}$ areas, the median (M), standard deviation (SD), the value of $t$ and $p$ (significance level ? 0.05), obtained using the T test .

Chart 1 shows, in percentages, participants who obtained scores classified as adequate and inadequate taking G1 into consideration, participants divided into very low birth weight (G1VLW), low birth weight (G1LW) and G2 (typical) by the ELM scale, in the AR, LA and V areas. 
TABLE 1 - Result obtained in the receptive auditory (RA), expressive auditory (EA) and visual (V) areas of the ELM, in regards to the $\mathrm{n}$ (M), standard deviation (SD) t and $\mathrm{p}$ value.

\begin{tabular}{|c|c|c|c|c|}
\hline RA & $\mathrm{M}$ & SD & $\mathrm{t}$ & $p$ \\
\hline \multirow[t]{2}{*}{ G1 } & 14,45 & 4,69 & & \\
\hline & & & $-4,6263$ & $0,0002^{*}$ \\
\hline G2 & 17,8 & 4,61 & & \\
\hline \multicolumn{5}{|l|}{$\mathrm{AE}$} \\
\hline \multirow[t]{2}{*}{ G1 } & 15,55 & 5,27 & & \\
\hline & & & $-2,9176$ & $0,0088^{*}$ \\
\hline $\mathrm{G} 2$ & 17,8 & & & \\
\hline \multicolumn{5}{|l|}{$\mathrm{V}$} \\
\hline G1 & 14,91 & 6,67 & $-2,3032$ & 0,0327* \\
\hline G2 & 17,8 & 4,61 & & \\
\hline
\end{tabular}

CHART 1. G1 (MBP e BP) and G2 performance by the ELM.

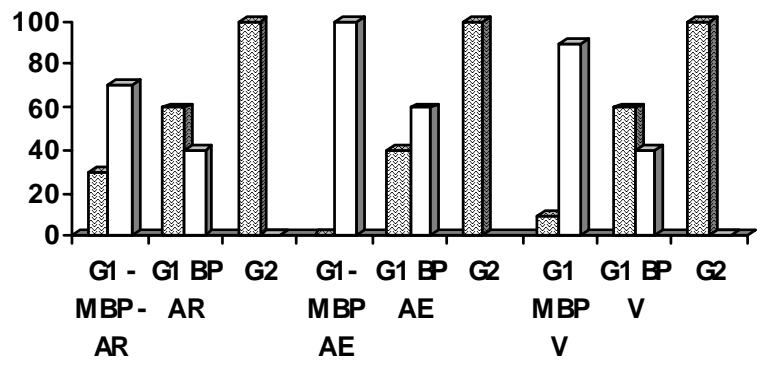

\section{Discussion}

Table 1 shows the comparison of performance of groups in three areas, RA, EA and V respectively, that were statistically different. The scores confirm the literature on the view that prematurity and low birth weight are risk factors for delayed development1-3,5-18.

The first years of life have been prioritized, as they are the stage of development characterized by major acquisitions in the motor, cognitive, linguistic and social areas, due to neuronal plasticity2.
Language development is common way to many neural systems, including hearing, vision, cognition, motor function and central processing of information8. In regards to development, one of the criteria of this population was to consider the neuropsychomotor development within standards viewed as typical for the two groups, since the delay or change in motor development can lead to the child missing real opportunities to expand his repertoire, leading to gaps in perceptual, cognitive, linguistic 
and social areas interfering, therefore, in the child's overall development. However, there is evidence that language development is delayed even if the preterm infant has presented appropriate gross motor development, as specified in a study5.

Literature shows that it is important to explore the mechanisms of development of premature and very low birth weight children associated to the abilities to process auditory and visual information, linking these skills to delays in language development and cognitive processes6. Regions of the brain are highly vulnerable to damage by hypoxia and periventrivular injuries such as periventricular leukomalacia, commonly associated with prematurity and very low weight, which can contribute to high incidence of language disorders2,5,6,8,15,17. Periventricular leukomalacia generally affects descendant motor fibers of the cortex and association fibers of the the visual, auditory and somesthetic functions, impacting the development of perceptive skills, interfering with language development15,17. It should be noted that the gap found in the development of premature infants may not necessarily be associated with brain lesions, but it means immaturity of the central nervous system which can serve as an indicator of development alterations2 ,8,9,12,14.

This population did not have any neurological assessment that could prove that these children had any brain insult; however, emphasis should be given to the importance of longitudinal follow up for these children.

It is possible to verify in Chart 1 that in relation to the RA, EA and V areas children with LBW showed greater lag than the LW group and when compared to the typical group, it was observed that the groups were statistically different (Table 1), although individuals in G1 presented appropriate scores. Studies showed that premature and low weight children generally lagged behind in receptive5, 111, 2 and expressive 1-2, 5-11, 13, 16 developments.

In the RA area, the delay can be related to immaturity in the attention abilities and in tasks which involve time and directing to the attentional focus, as verified in literature6,12. With regards to VLW children, it has been described6 that differences in language skills of premature and VLW can be part of an overall deficit of development, with impact to the cognitive functions. In regards to the expressive aspect, several studies2,5,8-7,10-11,16 reported that premature and LW infants showed delay and / or changes in this area. Researchers8, also using the ELM scale, observed delay in expressive function in preterm children, small for gestational age from the ninth month on. A study9 discussed that difficulties in language development are more apparent in the first years of life, but that their skills can improve with appropriate environmental stimulation. Social factors, such as socioeconomic status, mother's age, and parents' education level were questioned2 as factors that should be considered in addition to the biological abilities of these children.

The development of the visual function is also fundamental to the child's overall development and may be delayed by several conditions particularly by prematurity3,6,12,15,18. Prematurity can cause various ocular disorders such as strabismus, refractive errors, retinopathy, in addition to damage to the central vision. In this population, children had not been assessed by an ophthalmologist, but had follow ups with a pediatrician with no indication of changes. Alteration to the maturation of the visual system is highlighted in the studies14,18, which confirms the findings of this study.

The literature1-17 presents a consensus that premature and low birth weight children are at risk of presenting the language disorders by delays or disturbances in the receptive and expressive processes involving all linguistic levels, in addition to cognitive, sensory, and perceptive. Nevertheless, there is great variability in findings regarding children of low weight and prematurity and language development10. There is, however, the need for further studies so that we can better understand this process, considering the multifactorial factor involving child development, as it has been well presented in some studies5-6. In compiling the literature, we observed variability of the findings of studies on the overall development, communication skills and language development. The differences found can be attributed to characterization of the population studied such as age, differences in sample selection, size and sampling criteria, in addition to differences in assessment tools, forms of analysis and / or methodological limitations. However, these studies encourage reflection in relation to the need for a differentiated look at these individuals in the monitoring of their development.

It is worth mentioning that in this study, although G1 has performed statistically different from the typical group, the criterion of age adjustment was not used on the assessment procedures. This occurred due to several reasons. As shown in a study13, age adjustment for motor assessment of preterm infants has been a consensus, which does not occur in other areas of development. In assessing the development of visual function, it has been reported14 that in considering the visual development 
of a child born prematurely, there is no consensus whether to consider his adjusted gestational age or his chronological age. The authors reported that, in daily practice, there are no two children with the same development and great variability is observed between the premature ones oscillating between the two parameters. With age adjustment, some children of this population may have presented no delays and this way, preventive measures could have been postponed with deprivation to these individuals. We emphasize the importance of early assessment of children who present risk factors for development

\section{References}

1. Harding C, Gourlay S. New developments in the management of speech and language disorders. Arc Dis Child. 2008;93(7):425-27.

2. Maria-Mengel MRS, Linhares MBM. Risck factors for infant developmental problems. Rev Lat Enf. 2007;15(special issue):937-42.

3. Wohr BR. How should we report early childhood outcomes of very low bird weight infants? Seminars In Fetal Neonatal Med. 2007;12(5)355-12.

4. World Health Organization. International Classification of Impairments, Disabilities and Handicaps. Geneva: World Health Organization; 1980.

5. Jansson-Verkasalo E, Valkama M, Vainionpää l, Pääkkö E, Ilkko E, Lehtihalmes M. Language Development in very low birth weight preterm children: a follow-up study. Folia Phoniatr et Logop. 2004;56(2):109-19.

6. Ortiz-Mantilla S, Choudhurd N, Leevers H, Benasich AA. Understanding language and cognitive deficits in very low birth weight children. Dev Psychobiol. 2008;50(2):10726.

7. Rose SA, Jankowski JJ, Feldman JF, Rossem RV. Pathways from Premature and Infants Abilities to Later Cognition. Child Development. 2005;76(6):1172-84.

8. Oliveira LN, Lima MCM, Gonçalves VMG. Acompanhamento de lactentes com baixo peso ao nascimento: aquisição de linguagem. Arquivos de NeuroPsiquiatria. 2003;61(3):802-10.

9. Foster-Cohen S, Edgin JO, Champion PR, Woodward IJ. Early delayed language development in very preterm infants: evidence from MacArthur-Bates CDI. J Child Lang. 2007;34(3):655-75.

10. Ishii C, Miranda CS, Isotani SM, Perissinoto J. Caracterização de comportamentos linguísticos de crianças nascidas prematuras, aos quatro anos de idade. Rev Cefac. 2006;8(2):147-54. delay as well as longitudinal monitoring of their development, aiming to prevent alteration and to contribute to the study of the nature of these changes.

\section{Conclusion}

Premature and low birth weight children showed alterations in the RA, EA and V areas. When compared to the control group, they demonstrated to be statistically different. Premature children of very low birth weight showed greater losses in these evaluated areas.
11. Schimer CR, Portuguez MW, Nunes ML. Clinical assessment of language development in children at age 3 year that very born preterm. Arq Neuropsiquiat. 2006;64(4)926-931.

12. Caravale B, Tozzi C; Albino G, Vicari S. Cognitive development in low risk preterm infants at 3-4 years of life. Arch Dis Child Fetal Neonatal. 2005;90(6):474-9.

13. Pereira MR, Funayama CAR. Avaliação de alguns aspectos da aquisição e desenvolvimento da linguagem em crianças pré-termo. Arq Neuropsiquiatr. 2004;62(3-A):64148.

14. Graziano RM, Leone CR. Problemas oftalmológicos mais freqüentes e desenvolvimento visual em pré-termo extremo. J Pediatr. 2005;81(Suppl 1):S95-S100.

15. Crespo-Eguiláz N, Narbona J. Habilidades neurocognitivas de niños con leucomalácia periventricular Resultados preliminares em 15 sujetos. Rev Neurol. 2004;38(Suppl 1):S80-4.

16. Wolke D, Samara M, Bracewell M, Marlow N. Specific language difficulties and school achievement in child Born at 25 weeks of gestation or less. J Pediatr. 2008;152(2):256262.

17. Lamônica DAC, Ferraz PMDP. Periventricular leukomalacia and spastic diplegia: implications in the psycholinguistic abilities. Pró-Fono R. Atual. Cient. [online]. 2007;19,(4):357-62.

18. O'Connor AR, Fielder AR. Visual outcome and perinatal adversity. Seminars In Fetal Neonatal Med. 2007;12(5):40814.

19. Coplan J. Early Language Milestone Scale. 2nd. Texas: Pro-ed, 1994. 